\title{
Intensification of Cropping through Utilization of Fallow Period and Unutilized Land Resources in Bangladesh
}

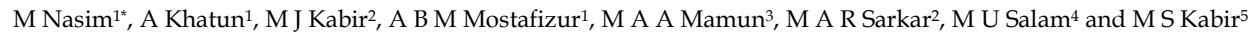

\begin{abstract}
Unavailability of suitable technologies including stress-tolerant cultivars, management options, irrigation facilities as well as extension supports are the key challenges for intensification of cropping through horizontal and vertical extension approaches. This study assesses the potential for increasing rice production through a horizontal extension approach. Historical and projected trend of area and production of rice, major cropping patterns and cropping intensity, as well as expert opinion, were the basis for extrapolation of the intensity of cropping by 2030. The analysis shows that about $1.52 \mathrm{M}$ ha area with fallow period of the existing major cropping patterns and $0.65 \mathrm{M}$ ha fallow land is potential for additional rice cropping. Resulting from that about 5.8 million tons additional rice can be added to total rice production in the country. An inclusion of a rice crop in certain percentage of the existing major cropping patterns, such as Boro-Fallow-T. Aman (25\%), Boro-Fallow-Fallow $(50 \%)$ and Fallow-Fallow-T. Aman (40\%) may contribute, respectively 1.38 million tons, 1.57 million tons and 0.80 million tons of rice in the total rice production. Besides, the addition of a certain percentage of cultural waste (50\%), marshy land (25\%), newly developed char land $(50 \%)$, and Jhum $(60 \%)$ and other extrapolation areas of Chittagong Hill Tract, respectively may contribute 0.4 million tons, 0.25 million tons, 0.34 million tons and 0.06 million tons rice in the total rice production. Strategic policy supports are required for implementing appropriate action plans to achieve the goals.
\end{abstract}

Key words: Utilizing fallow period, current fallow, culturable waste, increase rice area, rice production

\section{INTRODUCTION}

Government of Bangladesh in its sixth five years plan suggested both the horizontal (i.e., area expansion) and vertical (i.e., yield increase) extension approach to increase the food production in the country to meet up the demand for the growing population from the shrinking land resources. The country has to produce 44.6 million tons of clean rice by 2050 for 215.4 million populations (Kabir et al., 2015). There is a limited opportunity for increasing crop production in the favourable ecosystem through a vertical extension approach as cropping intensity in the area has reached about $200 \%$ (BBS, 2017b). On the other hand, there is an opportunity for increasing crop production through a horizontal extension approach in the stress-prone ecosystems in particular in the saline coastal, deep water, haor, char land ecosystem, and Chittagong Hill Tracts (CHT) where arable land is less intensively used than a favourable ecosystem. The rice is cultivated (i) in the three seasons in Bangladesh, (ii) occupies about $75 \%$ of the total cropped areas of the country (BBS, 2017b), and (iii) potential to cultivate on the slope of the hill to the area with stagnant water up to three meters.

It can be noted that crops other than rice are not suitable for cropping in the fields with stagnant water (Nasim et al., 2017). Therefore, rice has the potential for being introduced both in the favourable and unfavourable ecosystem for enhancing crop production in the country. However, the unavailability of suitable technologies including stress-tolerant cultivars and management options, irrigation facilities as well as extension supports are the key barriers

\footnotetext{
${ }^{1}$ Rice Farming Systems Division, Bangladesh Rice Research Institute (BRRI), Gazipur-1701, Bangladesh; ${ }^{2}$ Agricultural Economics Division, BRRI, Gazipur-1701, Bangladesh; ${ }^{3}$ Agricultural Statistics Division, BRRI, Gazipur-1701, Bangladesh; ${ }^{4}$ Freelance International Consultant (Agricultural Systems), Bangladesh; ${ }^{5}$ Director General, BRRI, Gazipur-1701, Bangladesh.

*Corresponding author's E-mail: nasimbrri@gmail.com (M Nasim)
} 
for increasing cropping in the stress-prone ecosystem through increasing cropping area. Understanding the existing cropping patterns, potential technologies, and strategies for improving the system productivity in a specific rice ecotype are the major concerns for boosting up total rice production. Nevertheless, none of the studies found to intensively assess opportunities for increasing rice production by implementing both the horizontal and vertical extension approaches. Thus, this study assesses the potential for increasing rice production through a horizontal extension approach by the inclusion of a rice crop in the fallow period in the major cropping patterns and utilizing current fallow and culturable waste both in the favourable and stress-prone ecosystem. Followed by the introduction, description of method is presented briefly. Thereafter, land utilization patterns, factors that contributed to rice production, extrapolation of total rice production by 2030 and conclusions are outlined.

\section{METHODOLOGY}

Secondary data were used for the study and mainly collected from different published sources including the Statistical Yearbook of Bangladesh (BBS, 2017a) and Year Book of Agriculture Statistics (BBS, 2017b). The future trend of various data until 2030 was projected based on historical data. Either 1969-70 or 1975-76 was considered as a baseline for the projection of future trends of different indicators subject to availability. Most of the data showed linear change over time; therefore, the best fit linear regression model was used to predict the future trends of different indicators to identify the way of boosting up rice production. The historical and projected trend of area, production of rice, and cropping intensity, as well as expert opinion, were considered as a basis for extrapolating the percentage of area is potential for inclusion a rice crop in the fallow period of the major cropping pattern and percentage of fallow land could be under rice cultivation in 2030 .

\section{RESULTS AND DISCUSSION}

\section{Land utilization pattern}

On average about $75 \%$ of the total cropped area of Bangladesh is used for rice cultivation (BBS, 2017b). Net cropped area of the country has decreased to 7.73 $\mathrm{M}$ ha in 2018-19 and will be decreased to $7.54 \mathrm{M}$ ha in 2030 (Fig. 1) as the arable lands are used for infrastructural development for shelter of the growing population, industries, and other purposes.

Despite that total rice and non-rice cropping area or total cropped area has been increasing, and will be increased in the future (Fig. 2) because of increasing cropping intensity. It was observed that cropping intensity increased to $195 \%$ in $2016-17$ at the rate of $0.65 \%$ and will be $215 \%$ by 2030 from $147 \%$ in 1969-70 (Fig. 3).

It indicates that some single-cropped areas transformed to a double-cropped area, some double-cropped areas to the triple-cropped area, and some triple-cropped areas to quadruple cropped area by accommodating rice or non-rice crops in the cropping patterns. It was observed that a single cropped area shows a decreasing trend under historical (1975-76) and future conditions (2019/20-2030/31). On the contrary, the doubled cropped area shows an increasing trend under historical conditions (until 2017-18) and decreasing trend under future conditions. Besides, tripled cropped area shows an increasing trend under historical (1975-76) and future conditions (2019-20 to 2030-31), consequently cropping intensity in the country will be increased further in the future (Fig. 3). It can be noted that cropping in the country substantially changed because of the development and dissemination of new generation short duration rice and non-rice cultivars to fit into the fallow period in the existing single and two crops-based cropping patterns. Percent contribution of rice and nonrice crops to total cropped areas showed an opposite trend (Fig. 8). Additionally, the availability of other green revolution 
technologies including chemical fertilizers, instance, irrigated Boro rice in the dry season pesticides, and irrigation facilities also was cultivated in about $4.86 \mathrm{M}$ ha due to the contributed to increasing cropping intensity. For availability of irrigation facilities (BBS, 2017b).

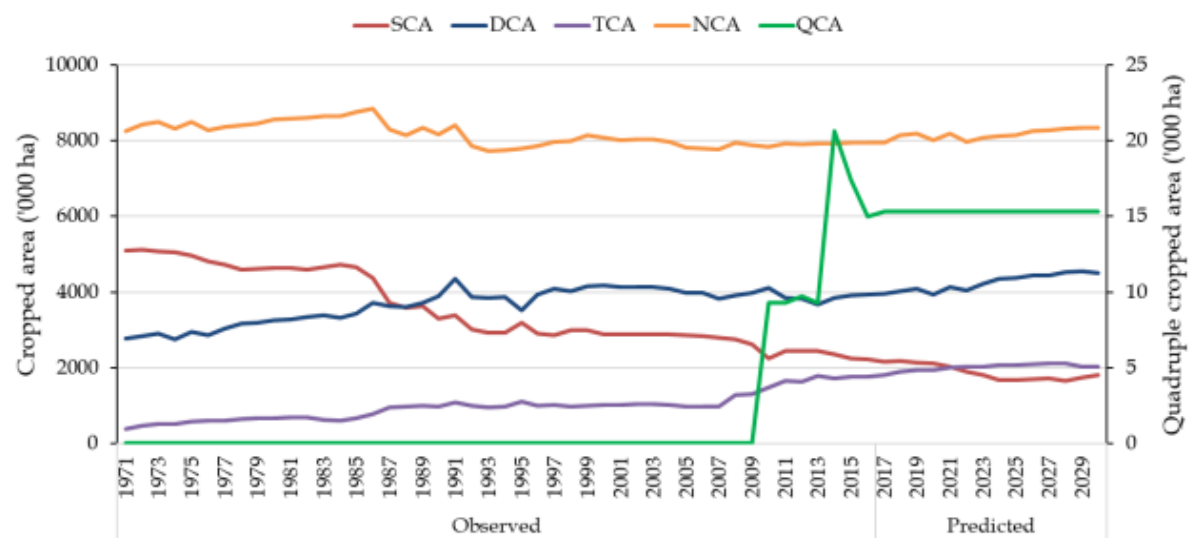

Fig. 1. Trend of single cropped area (SCA), double-cropped area (DCA), triple cropped area (TCA), quadruple cropped area (QCA) and net cropped area (NCA).

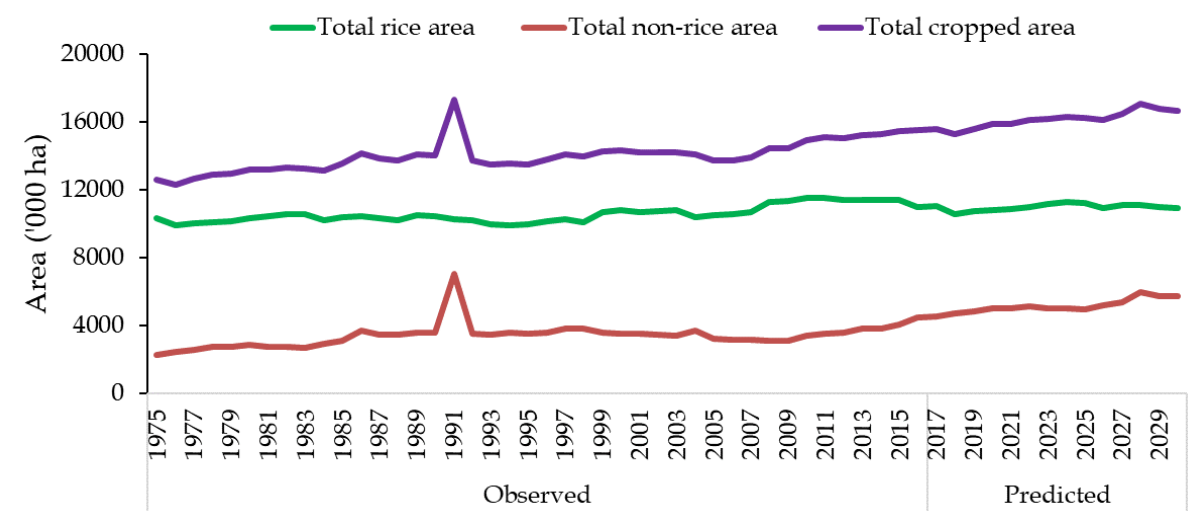

Fig. 2. Trend of total cropped area, total rice area and total non-rice area during 1974-75 to 2030-31 in Bangladesh.

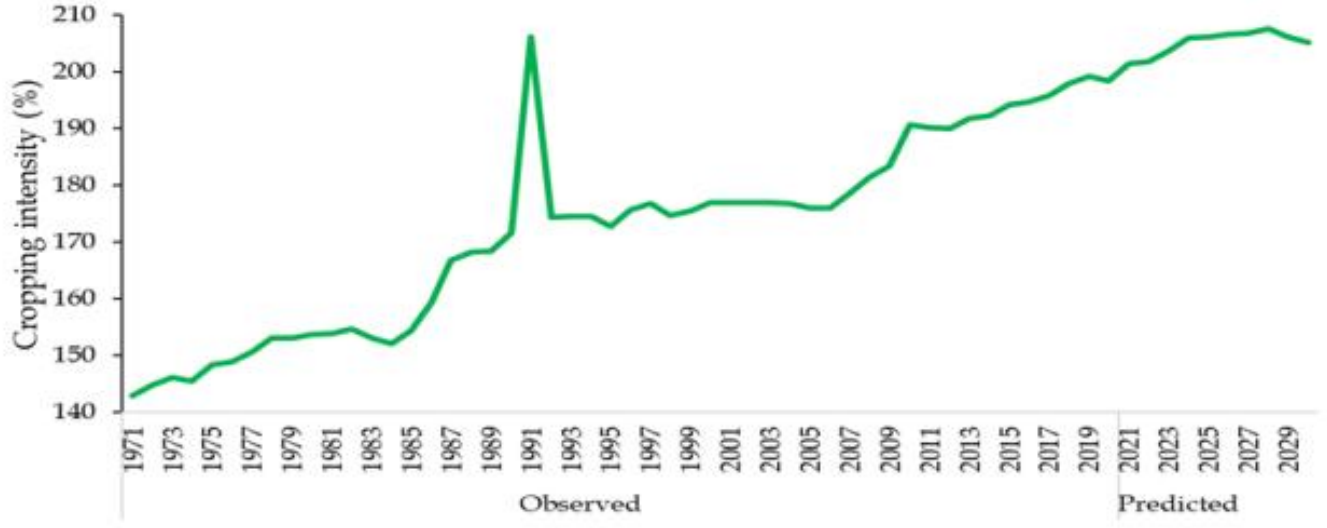

Fig. 3. Trend of cropping intensity during 1970-71 to 2030-31 in Bangladesh. 


\section{Factors contributed in rice production}

Total rice production in the country increased to 34.07 million tons in 2017-18, which is about three times higher than that of baseline in 197576 (Fig. 4). Increased total rice cropped area (Fig. 2) and yield (Fig. 5) are jointly contributed to an increase in total rice production. We estimated the contribution of total rice area increase in total rice production through considering current rice yield $\left(3.12 \mathrm{t} \mathrm{ha}^{-1}\right)$ for 9.68 $\mathrm{M}$ ha total rice cropped area in 1975-76.

Total rice production in $1975-76$ at the current yield is 30.21 million tons, which was 4.15 million tons lower than total rice production (34.36 million tons) in 2017-18. This analysis indicates that 4.15 million tons of rice production have increased only because of increasing total rice cropped areas for increasing cropping intensity. Thus it is evident that it is possible to increase total rice production by increasing cropping intensity.

The contribution of increased yield on total rice production was estimated by calculating the contribution of better genotype, agronomic management, chemical fertilizer, and irrigation. The estimated baseline total rice production for $9.68 \mathrm{M}$ ha at $1.22 \mathrm{t} \mathrm{ha}^{-1}$ yield for local cultivars in 1975-76 was 11.81 million tons. The contribution of higher yield potential modern cultivars, agronomic practice, chemical fertilizer, and improved irrigation facilities in total rice production (18.4 million ton) was estimated by subtracting baseline total rice production (11.81 million ton) from the extrapolated total rice production (30.21 million ton) in 1975-76 at current yield. Figure 6 presents baseline total rice production (11.81 million tons), increased rice production for increased total rice cropped area (4.15 million tons), and the adoption of higher yield potential modern cultivars, agronomic practice, fertilizer, and irrigation application (18.4 million tons). The results indicate that the adoption of green revolution technologies in particular modern cultivars, chemical fertilizers, and irrigation substantially contributed to increasing total rice production followed by increased area. Therefore, it can be claimed that it is possible to increase total rice production through the adoption of higher yield potential better genotype, and improved agronomic practices.

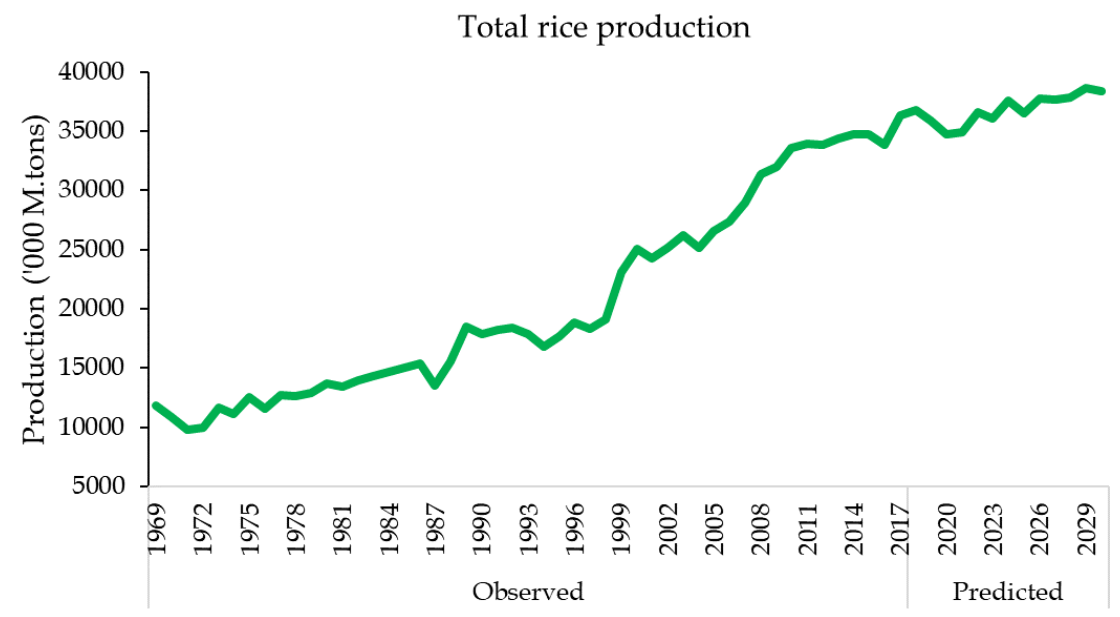

Fig. 4. Trend of total rice production during 1969-70 to 2030-31 in Bangladesh. 


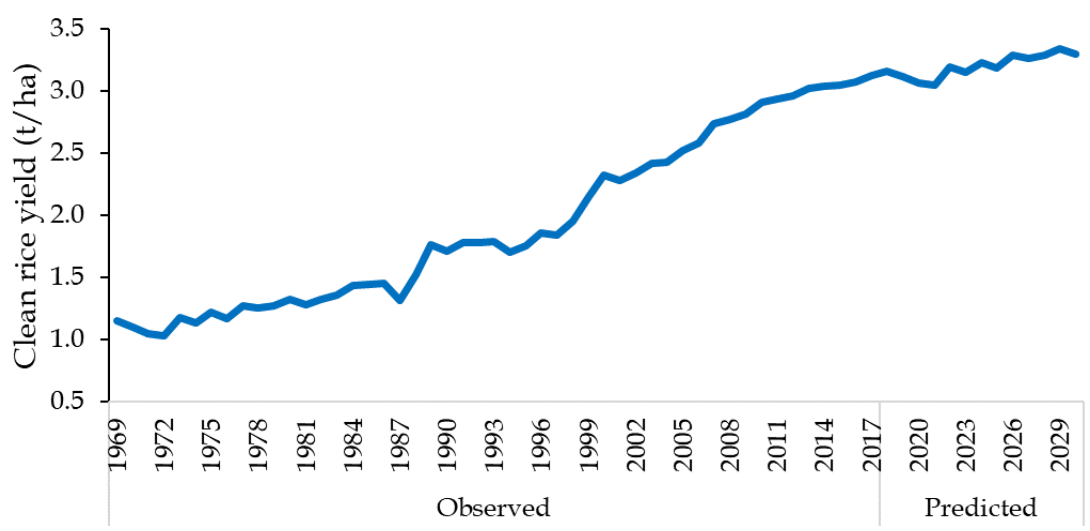

Fig. 5. Trend of total rice yield during 1969-70 to 2030-31 in Bangladesh.

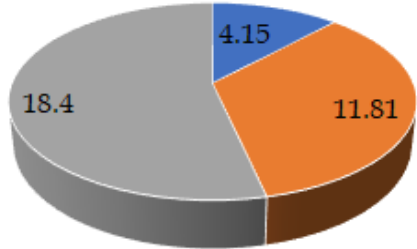

\footnotetext{
- Baseline production in 1975-76 using local cultivars (Million ton)

- Production increase because of increasing total rice area (Million ton)

= Production increase because of adoption improved cultivars and management (Million ton)
}

Fig. 6. Contribution of rice area intensification, high yielding variety and modern management practices and base production by local varieties to total rice production in Bangladesh.

\section{Extrapolation of total rice production}

In this study, total rice production in 2030 is extrapolated based on (i) increased total rice cropped area through increased cropping intensity by adopting another rice crop in the fallow period in the existing major cropping patterns and (ii) bringing the current fallow and culturable waste area under rice cultivation will increase rice production. Likewise, it is reported that there is potential for enhancing rice production by introducing rice in the underutilized areas in Barishal, Sylhet, Khulna, and Jashore (Kabir et al., 2020). The following measures could facilitate increasing total rice production to achieve SDGs.

Firstly, from the afore mentioned discussion, it is understandable that there is an opportunity for boosting total rice production in the country through the inclusion of a rice crop in the existing cropping pattern. Table 1 presents the fifteen most dominant cropping patterns in Bangladesh. It was observed that there is a notable scope for increasing cropping intensity in the country through the inclusion of one or two rice and non-rice crops in the existing cropping pattern by utilizing available technologies and developing suitable cultivars and component technologies. Boro in the dry season followed by fallow in the early wet season and T. Aman in the wet season was the most dominant cropping pattern in the country, covers about $27 \%$ of the total net cropped area. It indicates that about $27 \%$ of the total net cropped area in the country remains 
fallow in the early wet season for about four months in between Boro and T. Aman rice.

On the other hand, despite the reduction trend of Aus area (Fig. 7) the country has a higher yield potential of medium growth duration Aus rice cultivar (BRRI dhan 48 and BRRI dhan83) for fitting into the cropping pattern. Additionally, there are facilities for supplementary irrigation in most areas for establishing Aus rice on time if no rain occurs on time, and the government has given special attention to developing surface water irrigation facilities in the coastal areas through re-excavation of canals. Thus, it can be claimed that there is an ample opportunity for boosting rice production in the country through the inclusion of another rice crop in between Boro and T. Aman subject to ensuring the availability of seed for Aus cultivars, the extension supports, and most importantly access to the fair price of rice grain to make it economically viable. If we can bring $20 \%$ of the total area of the cropping pattern $(0.576 \mathrm{M} \mathrm{ha})$ under Aus rice cultivation that can add 1.38 million tons of rice in the total rice production with a $3.0 \mathrm{t} \mathrm{ha}^{-1}$ yield. Similarly, there is a potential for the inclusion of Boro rice in the $5^{\text {th }}$ most dominant cropping pattern (Fallow-AusT. Aman) in some areas for increasing total rice production by developing irrigation facilities.

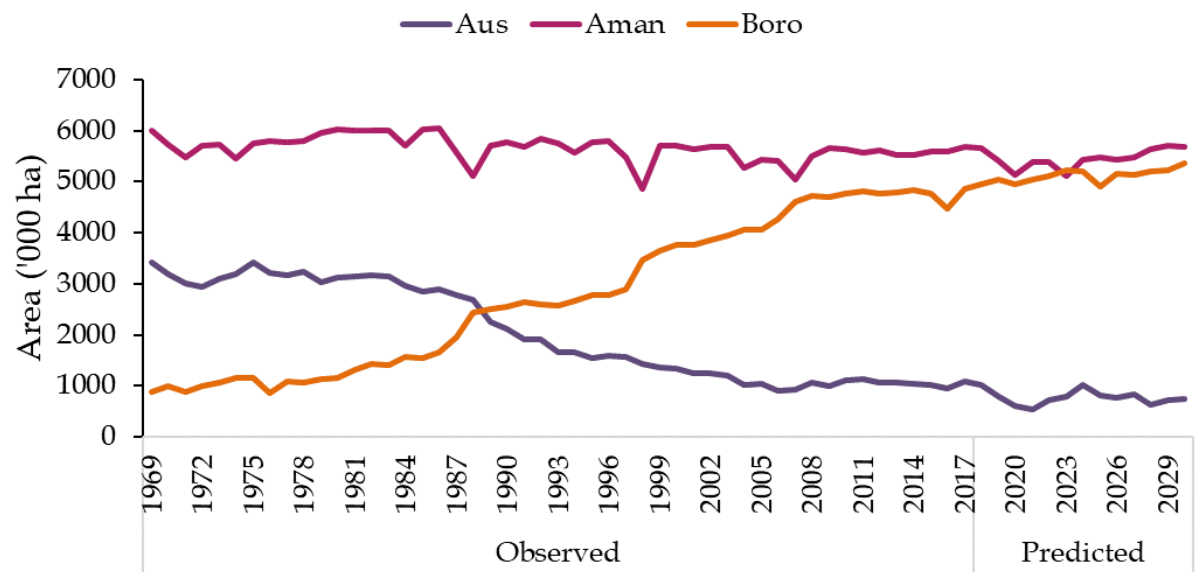

Fig. 7. Trend of Aus, Aman and Boro area during 1969-70 to 2030-31 in Bangladesh.

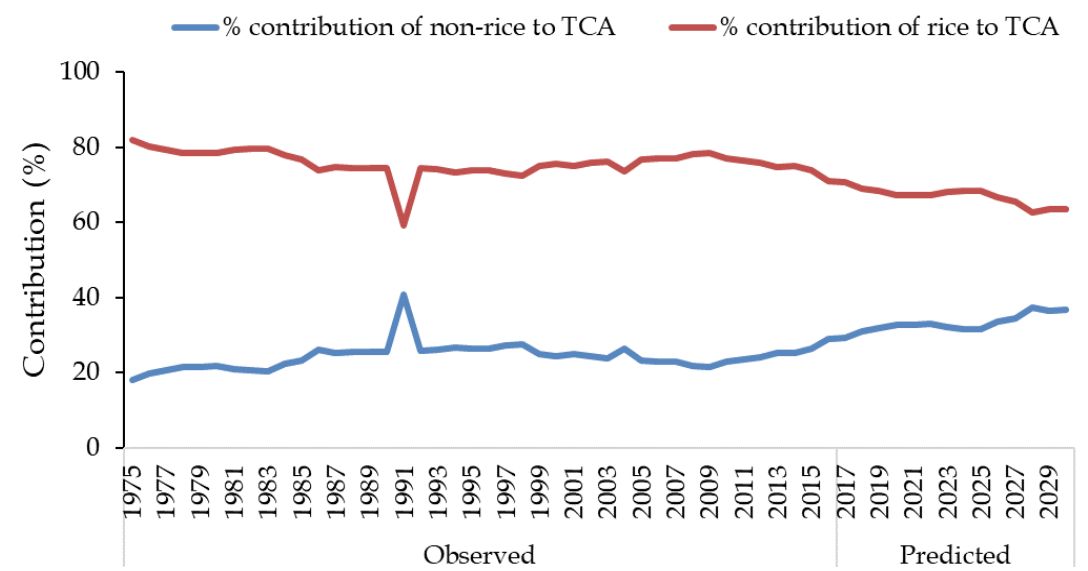

Fig. 8. Trend of percent contribution of rice and non-rice area to total cropped area during 1974-75 to 2030-31 in Bangladesh.

94 Nasim et al. 
Table 1. List of dominant cropping patterns in Bangladesh, 2014-15.

\begin{tabular}{|l|l|l|l|l|}
\hline Cropping pattern & Area (ha) & NCA (\%) & District (No.) & Upazila (No.) \\
\hline Boro-Fallow-T. Aman & 2306,005 & 26.919 & 63 & 426 \\
\hline Boro-Fallow-Fallow & 1139,530 & 13.302 & 59 & 342 \\
\hline Fallow-Fallow-T. Aman & 509,480 & 5.947 & 36 & 162 \\
\hline Boro-Aus-T. Aman & 209,015 & 2.440 & 47 & 177 \\
\hline Fallow-Aus-T. Aman & 193,275 & 2.256 & 30 & 108 \\
\hline Mustard-Boro-T. Aman & 184,620 & 2.155 & 51 & 203 \\
\hline Boro-B. Aman & 183,070 & 2.137 & 32 & 113 \\
\hline Potato-Boro-T. Aman & 180,380 & 2.106 & 33 & 115 \\
\hline Wheat-Jute-T. Aman & 147,210 & 1.718 & 43 & 216 \\
\hline Veg.-Veg.-Veg. & 143,270 & 1.672 & 61 & 283 \\
\hline Mustard-Boro-Fallow & 143,130 & 1.671 & 37 & 112 \\
\hline Grasspea-Fallow-T. Aman & 108,150 & 1.262 & 25 & 80 \\
\hline Maize-Fallow-T. Aman & 101,460 & 1.184 & 39 & 126 \\
\hline Wheat-Fallow-T. Aman & 90,910 & 1.061 & 39 & \\
\hline Mungbean-Fallow-T. Aman & 89,650 & 22 & \\
\hline
\end{tabular}

Source: Adopted from Nasim et al., 2017. Note: NCA= Net cropped area, Veg.= Vegetables

Secondly, Boro in the dry season, followed by fallow in the early wet season, and the wet season is the second most dominant cropping pattern, covers about $13 \%$ of the total net cropped area (1.134 M ha). Besides, mustard in the dry season followed by Boro in the dry season and fallow in the wet season is the eleventh most dominant cropping pattern, covers about $1.67 \%$ ( $0.143 \mathrm{M}$ ha) of net cropped area (Table 1). The main reason for remaining fallow in the wet season of the cropping patterns is that the area remains under at least $50 \mathrm{~cm}$ stagnant water for about a month. Furthermore, the unavailability of higher yield potential semi-deep water-tolerant wet season rice cultivars is a reason for the remaining fallow of the area in the wet season as lower yield potential local cultivars (1-1.5 $\left.\mathrm{t} \mathrm{ha}^{-1}\right)$ is not profitable. On average about $1 \mathrm{M}$ ha semi deep-water areas remain fallow in the wet season which is the potential for growing a rice crop in the wet season (Kabir et al., 2018). It indicates that there is also a potential for inclusion of a rice crop in the wet season in the second and eleventh most dominant cropping pattern as BRRI has already developed semi deep-water cultivar BRRI dhan91 (3.5 t ha-1), and there are some local cultivars that perform well under stagnant water condition. If we can bring about $50 \%$ of the total areas of the cropping patterns, consequently an additional $0.641 \mathrm{M}$ ha of land will be under cultivation of deep-water rice, which can contribute an additional 1.57 million tons of rice to total rice production. The additional rice production was estimated for a 0.641 ha area with a $2.45 \mathrm{t}$ ha $^{-1}$ yield with a $30 \%$ yield gap for BRRI dhan91 in stress conditions.

Thirdly, fallow in the dry season followed by fallow in the early wet season and T. Aman in the wet season was the third most dominant cropping pattern, cover about $6 \%$ of the total net cropped area (0.509 M ha) (Table 1$)$. This cropping pattern is mainly located in Madhupur and Barind Tract, tidal saline, and non-saline coastal zone and the Chittagong Hill Tracts. Similarly, it is reported that Fallow-Fallow-T. Aman was the dominant cropping pattern in the tidal non-saline ecosystem in the Barishal region (Ibrahim et al., 2017). Besides, Fallow-Fallow-T. Aman and Fallow-Aus-T. Aman was the major cropping pattern in the Sylhet region (Muttaleb et al., 2017). The area remains fallow in the dry to early wet season mainly because of the unavailability of freshwater for irrigation in crops in the dry season. Besides, salinity and unavailability of the seed of saline tolerant 
cultivars is also a practical barrier for cropping in the dry and early wet season in the coastal region. It can be noted that the development of surface water irrigation facilities through the re-excavation of canals in the non-saline Barishal region can create an opportunity for the inclusion of rice or non-rice crops in the dry season in the existing Fallow-Fallow-T. Aman cropping pattern. Besides, dredging some areas of the river for following freshwater water from the upstream river to the downstream river in the tidal saline ecosystem in the coastal region may create an opportunity for storing freshwater in the river for irrigation in Boro rice. Moreover, trapping freshwater in the canals through closing sluice gate or constructing earthen embankment between canals and rivers in early December could be used for Boro rice cultivation in coastal regions.

If it is possible to reserve adequate freshwater for irrigation through strong policy supports for developing the above-mentioned facilities it may be possible to bring $40 \%$ of the total area of the cropping pattern (FallowFallow-T. Aman) under Boro rice cultivation (e.g., 0.2 million ha) through the adoption of BRRI developed saline tolerant $(8-10 \mathrm{dS} / \mathrm{m})$ rice cultivar BRRI dhan67. The extrapolated additional rice production for the inclusion of Boro rice in the $0.2 \mathrm{M}$ ha with a $3.96 \mathrm{t} \mathrm{ha}^{-1}$ yield is about 0.80 million tons of rice. Similarly, it is reported that there was potential to include Boro and even the Aus rice in the FallowFallow-T. Aman cropping pattern in the nonsaline tidal and haor ecosystems if access to irrigation water is ensured (Ibrahim et al. 2017; Muttaleb et al. 2017). Furthermore, there was potential for introducing T. Aman rice in the Mustard-Boro-Fallow cropping patterns (Table 1). There was also potential for introducing deepwater rice in the wet season in the BoroFallow-Fallow cropping pattern. Similarly, there was potential for introducing Boro and Aus rice in the (i) Grasspea-Fallow-T. Aman, (ii) Maize-Fallow-T. Aman, (iii) Wheat-FallowT. Aman and (iv) Mungbean-Fallow-T. Aman cropping patterns (Table 1).

Fourthly, some of the arable areas remain fallow round the year as current fallow and culturable waste. Some areas remain fallow because of absentee farmers and some areas are newly developed in riverine Char land etc. It was observed that current fallow land will be $0.3 \mathrm{M}$ ha and culturable waste will be $0.2 \mathrm{M}$ ha in 2030 (Fig. 9).

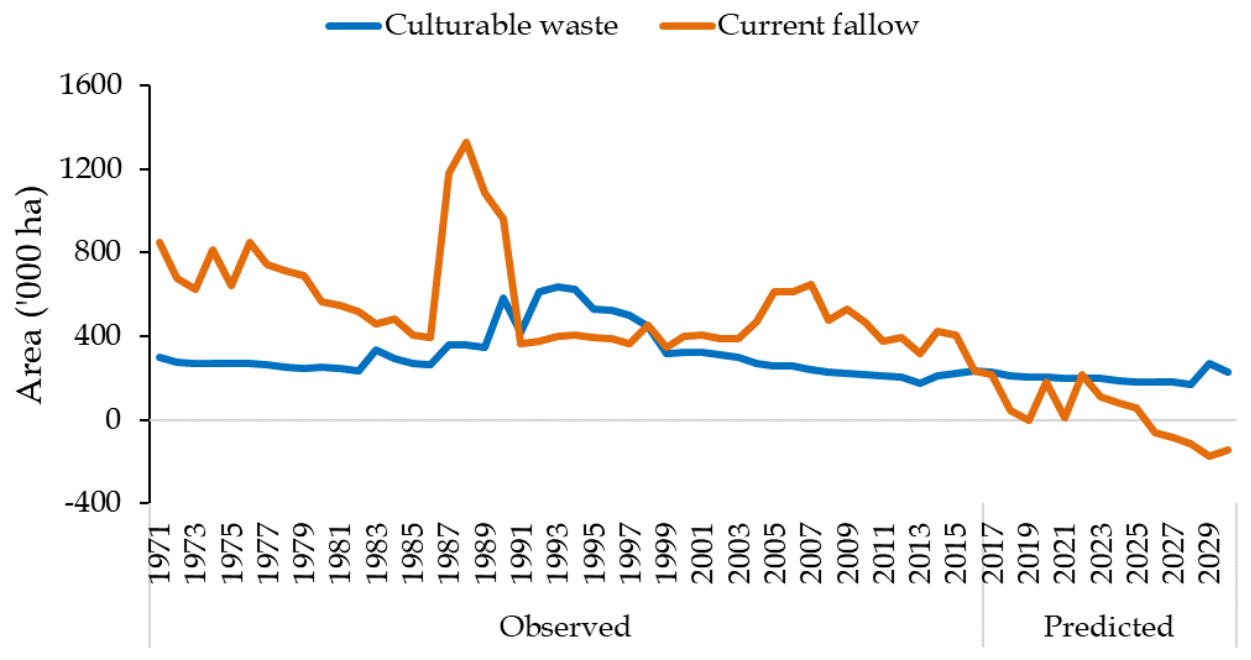

Fig. 9. Trend of culturable waste and current fallow during 1970-71 to 2030-31 in Bangladesh. 
Similarly reported that there is an opportunity for enhancing rice production in the cultural wastelands in coastal Char lands in Barishal and Noakhali (Kabir et al., 2020). If it is possible to bring $50 \%$ of these areas (0.25 M ha) under rice cultivation through providing appropriate technologies and extension supports we can add additional 0.99 million tons of rice in the total rice production with a $3.96 \mathrm{t} \mathrm{ha}^{-1}$ yield.

Fifthly, there is some marshy land such as Vabadaha and Bhutiar beel which mostly remains fallow round the year due to stagnant water because of inadequate drainage facilities. If it is possible to develop irrigation facilities through the excavation of canals, the area might come under Boro rice cropping. If we can bring $0.25 \mathrm{M}$ ha under Boro rice cultivation, it can contribute 0.99 million tons to total rice production with a $3.96 \mathrm{t} \mathrm{ha}^{-1}$ yield.

Sixthly, the ethnic minorities in Chittagram Hill Tracts (CHT) grow crops by the hill agriculture (jhum) and plain land agriculture (plow agriculture). However, 22,413 jhum farmers are about $13 \%$ of total farm households in the CHT, most of them are not self-sufficient in rice production for their family subsistence for round the year. It was partly because of productivity of local cultivars Aus rice under the jhum system was low and partly because about $80 \%$ of the total $0.129 \mathrm{M}$ ha arable land in the valley used only for rainfed rice cropping in the wet season. It can be noted that Fallow-Fallow-T. Aman is the second most dominant cropping pattern in CHT (Quais et al., 2017). However, there is fresh surface water in the rivers, lakes, canals, and springs for irrigation as well as there is underground water for both shallow and deep aquifers irrigation in CHT. Besides, there is potential for reserving rainwater in the tank on the top of hills and excavating reservoirs or crick/cross dam or mini ponds for irrigation as more rainfall occurs in the
CHT. Therefore, there is potential for increasing rice production by introducing Boro rice in $45 \%$ of the single T. Aman-based cropping pattern through developing infrastructure for irrigation (reservoirs and channels). Likewise, it is reported that there is an opportunity for enhancing rice production in the Chittagong Hill Tract (CHT) (Kabir et al., 2020).

Besides, the fallow in the wet season followed by non-rice crops in the dry season and followed by Aus rice in the early wet season is the cropping system of $0.012 \mathrm{M}$ ha jhum culture area in CHT and per hectare yield of Aus rice under jhum system was 1.20 $\mathrm{t} \mathrm{ha}^{-1}$ (BRRI, 2019). Therefore, there is a potential for increasing 0.017 million tons production of Aus rice by (i) replacing local cultivars by the higher yield potential modern rice cultivators $\left(3.5 \mathrm{t} \mathrm{ha}^{-1}\right)$ about $60 \%$ of total jhum culture area, and (ii) improving agronomic management.

Moreover, there is about $0.0136 \mathrm{M}$ ha culturable waste land in Kaptai Lake at CHT. However, the area has potential for cropping rice and non-rice crops in the dry season (January- May) through rescheduling the time of opening sluice gates for drainage out the water from the Lake. Additional 0.0269 million tons of rice could be added to the national rice basket through introducing Boro rice in the $50 \%$ of the total culturable waste (0.0067 M ha) land of Kaptai lake subject to small intervention for (i) developing irrigation facilities and (ii) rescheduling the time of drainage out the lake water after harvesting Boro rice. These results indicate that increased total rice production not only will be played a vital role in increasing selfsufficiency in rice production at CHT but also will be contributed to improving livelihood through increasing farm income and generating employment opportunities for the wage workers. 
Finally, there are some areas such as char land, mudflat and sandy beaches which are potential for cropping. These accreted lands have been increasing and will be increased in the future (Hasan et. al., 2013). There are about $0.55 \mathrm{M}$ ha accreted land which has the potential to contribute to the total rice production. However, some of the areas are not suitable for rice cropping and even there is no settlement in some areas as well. Therefore, it needs to shift people for the ricegrowing period. If it is possible to bring $50 \%$ of the area (0.275 M ha) under local cultivars rice cultivation with $1.22 \mathrm{t} \mathrm{ha}^{-1}$ yield potential, it can contribute about 0.34 -million-ton rice in the total production.

\section{Research, development and extension activities for enhancing rice production}

Table 2 presents a detailed research plan for increasing rice production through cropping in the fallow period and unutilized area. Mainly on-farm research trials are needed to conduct for identifying the potential for cropping system intensification in the appropriate domains. Besides, large-scale demonstrations are needed to set for boosting farmers' confidence about the potential of introducing rice in the fallow period and unexplored areas. Moreover, farmers' field days are required to arrange and broadcast the success story in the print and electronic media for informing the potential of farmers across the country.

Table 3 presents the target for enhancing rice area by introducing rice in the fallow period and the unexplored areas across future conditions. The research and upscaling activities will be undertaken in different selected upazilas and districts sequentially. Thirty-five percent target of introducing rice in the fallow period and unexplored areas will be achieved by 202130. Thereafter, about $35 \%$ target of introducing rice in the fallow period and unexplored areas will be achieved by 203140. Finally, about $30 \%$ target of introducing rice in the fallow period and unexplored areas will be achieved by 2041-50.

Table 2. Research, development and extension activities for increasing rice production through cropping in fallow period and unutilized area.

\begin{tabular}{|c|c|}
\hline Phase & Activity \\
\hline \multirow{4}{*}{$\begin{array}{l}\text { Research } \\
\text { development }\end{array}$} & 1. Site selection and characterization through baseline survey (PRA, FGD) and SWOT analysis. \\
\hline & $\begin{array}{l}\text { 2. Scope validation trials for introducing rice in the existing cropping patterns }(\mathrm{CP}) \text { and } \\
\text { unutilized areas. The main aim of the activity is to identify problems and prospects of } \\
\text { improving existing CPs. Demonstration trials will set on fields of the selected progressive } \\
\text { farmers to achieve the goal. }\end{array}$ \\
\hline & $\begin{array}{l}\text { 4. Informing farmers about the potential of introducing rice in the existing CPs and unutilized } \\
\text { areas through print and electronic media. }\end{array}$ \\
\hline & $\begin{array}{l}\text { 5. Large-scale demonstrations will be set on farmers' fields and field days will be arranged to } \\
\text { present the potential to mass farmers of nearby villages. }\end{array}$ \\
\hline Extension & $\begin{array}{l}\text { 8. The success story will be widely broadcasted in print and electronic media for motivating } \\
\text { farmers and extension personnel. }\end{array}$ \\
\hline
\end{tabular}


Table 3. Targeted cropping patterns and areas for introducing rice in the fallow period and unexplored areas across future conditions.

\begin{tabular}{|c|c|c|c|c|c|c|}
\hline \multirow{2}{*}{$\begin{array}{l}\text { Cropping pattern }(\mathrm{CP}) / \text { Intervention/ } \\
\text { Ecosystem }\end{array}$} & \multirow{2}{*}{$\begin{array}{l}\text { Area of } \\
\text { ECP (ha) }\end{array}$} & \multirow{2}{*}{$\begin{array}{l}\text { Targeted area } \\
\text { to introduce } \\
\text { rice (ha) }\end{array}$} & \multirow{2}{*}{$\begin{array}{l}\text { Extrapolated } \\
\text { production } \\
\text { increase (MT) }\end{array}$} & \multicolumn{3}{|c|}{ Activities (Table 2) } \\
\hline & & & & $2021-30$ & $2031-40$ & $2041-50$ \\
\hline \multicolumn{7}{|l|}{ Cropping in fallow period of $\mathrm{CP}$} \\
\hline $\begin{array}{l}\text { ECP: Boro-Fallow-T. Aman } \\
\text { ICP: Boro-Aus-T. Aman }\end{array}$ & $23,06,005$ & $5,76,000$ & 1.38 & $1-8$ & $1-8$ & $1-8$ \\
\hline $\begin{array}{l}\text { ECP1: Boro-Fallow-Fallow } \\
\text { ECP2:Mustard-Boro-Fallow } \\
\text { ICP1: Boro-Deepwater rice } \\
\text { ICP2:Mustard-Boro-Deepwater rice }\end{array}$ & $\begin{array}{l}11,39,530 \\
1,43,130\end{array}$ & $\begin{array}{l}5,69,765 \\
71,565\end{array}$ & 1.57 & $1-8$ & $1-8$ & $1-8$ \\
\hline $\begin{array}{l}\text { ECP:Fallow-Fallow-T. Aman } \\
\text { ICP1: Fallow-Aus-T. Aman } \\
\text { ICP2: Boro-Aus-T. Aman }\end{array}$ & $5,09,480$ & $2,03,792$ & 0.80 & $1-8$ & $1-8$ & $1-8$ \\
\hline $\begin{array}{l}\text { ECP:Grasspea/Maize/Wheat/ } \\
\text { Mungbean-Fallow-T. Aman } \\
\text { ICP:Grasspea/Maize/Wheat/ } \\
\text { Mungbean-Aus-T. Aman }\end{array}$ & $3,00,520$ & 97,542 & 0.29 & $1-8$ & $1-8$ & $1-8$ \\
\hline \multicolumn{7}{|l|}{ Utilization of unexplored area } \\
\hline Cultivable waste & 200,000 & 100,000 & 0.40 & $1-8$ & $1-8$ & $1-8$ \\
\hline Stagnant water area & 250,000 & 62,500 & 0.25 & $1-8$ & $1-8$ & $1-8$ \\
\hline Char land & 550,000 & 275,000 & 0.34 & $1-8$ & $1-8$ & $1-8$ \\
\hline Hilly area & 43,210 & 23,102 & 0.061 & $1-8$ & $1-8$ & $1-8$ \\
\hline
\end{tabular}

CP: Cropping pattern, ICP: Improved cropping pattern, ECP: Existing cropping pattern

\section{CONCLUSION}

Sustainable intensification of rice cropping might be possible for meeting up food security challenges for the growing population in 2030 through the introduction of a rice crop in 2.211 $M$ ha in the fallow period in the existing major cropping patterns and utilizing fallow land for rice cropping. About six million tons of additional rice can be added to total rice production through strengthening policy supports for implementing appropriate action plans to achieve the goals.

\section{RECOMMENDATION}

- Strategic policy support for developing must needed infrastructure for freshwater reserve and strengthening research for developing technologies is required for intensification of cropping through (i) transforming some major existing cropping patterns by utilizing the fallow period and (ii) utilizing the fallow lands for higher and sustainable growth in rice production.

- Suitable rice cultivars and component technologies are needed to be developed to fit into the existing major cropping pattern and disseminate in the unutilized land.

- Extension supports (training and largescale demonstration) need to be strengthened for improving farmers' knowledge about component technologies through training and large-scale demonstration for adopting another rice crop in the fallow period and grow the crop in the unutilized land.

- The seed of suitable rice cultivars should be available at the farm level.

- Improvement in irrigation systems and excavation of silted up canals or rivers should be developed to expand the irrigated areas 
- The fair price of paddy rice needs to be ensured to make the enterprise economically viable for motivating farmers for investing their time and money in cultivating an additional rice crop as most farmers are self-sufficient in rice production from the existing cropping pattern.

\section{ACKNOWLEDGEMENTS}

The authors wish to thank anonymous reviewers for their suggestions, which significantly improved this article.

\section{AUTHORS' CONTRIBUTION}

MN, AK, MUS and MSK generated idea; MUS, MARS and MAAM coordinated the research; $\mathrm{MN}$, ABMM and MJK developed methodology; MN, AK, MJK, ABMM, MARS, MUS and MSK provided scientific insights; $\mathrm{MN}, \mathrm{AK}, \mathrm{ABMM}$ and MAAM gathered data, carried out analysis and synthesis; $\mathrm{MN}, \mathrm{AK}$, MJK and ABMM did the writings for all versions of the manuscript; MJK, MAAM, MARS and MUS performed critical review and editing; All authors read and approved the final manuscript.

\section{DECLARATION OF INTERESTS}

A version of the paper was published in a book "Doubling Rice Productivity in Bangladesh" in 2020 by the Bangladesh Rice Research Institute (BRRI), Gazipur 1701, Bangladesh to commemorate BRRI's 50, th anniversary. The Bangladesh Rice Journal has prior knowledge of the book publication and does not see any conflict of interest.

\section{REFERENCES}

BBS (Bangladesh Bureau of Statistics). 2017a. Statistical Yearbook of Bangladesh-2016. Bangladesh Bureau of Statistics (BBS), Statistics and Informatics Division, Ministry of Planning, Government of the People's Republic of Bangladesh, Dhaka, Bangladesh.

BBS (Bangladesh Bureau of Statistics). 2017b. Yearbook of Agricultural Statistics-2016. Bangladesh Bureau of
Statistics (BBS), Statistics and Informatics Division, Ministry of Planning, Government of the People's Republic of Bangladesh, Dhaka, Bangladesh.

Hasan, M N, M S Hossain, M A Bari and M R Islam. 2013. Agricultural land Availability in Bangladesh. Soil Resource Development Institute (SRDI), Dhaka, Bangladesh, 28-42.

Ibrahim, M, M A U Zaman, A B M Mostafizur and S M Shahidullah. 2017. Diversity of Crops and Land Use Pattern in Barishal Region. Bangladesh Rice Journal, 21 (2): 57-72.

BRRI (Bangladesh Rice Research Institute). 2019. Economics of Jhum cultivation in Bangladesh. Annual report 2018-19, Bangladesh Rice Research Institute, Gazipur-1701, Bangladesh. 172-173

Kabir, M S, M U Salam, A K M S Islam, M A R Sarkar, M A AMamun, M C Rahman, B Nessa, M J Kabir, H B Shozib, M B Hossain, A Chowdhury, M Nasim, K M Iftekharuddaula, M S Hossain, M K A Bhuiyan, B Karmakar, M S Rahman, M M Haque, M T Khatun, M P Ali, S M H A Rabbi, P L Biswas, E S M H Rashid and N M F Rahman. 2020. Doubling rice productivity in Bangladesh: A way to achieving SDG 2 and moving forward. Bangladesh Rice Journal, 24 (2): 1-47.

Kabir, M J, K M Iftekharuddaula, T L Aditya and M S Kabir. 2018. Rice Technological Innovation and Value Chain Development in Bangladesh: Current Status and Future Directions (Chapter-3). Pandey P R, Bhandari H (eds.) 2018. Rice Technological Innovation and Value Chain Development in South Asia: Current Status and Future Directions: SAARC Agriculture Centre, 22-48.

Kabir, M S, M U Salam, A Chowdhury, N M F Rahman, K M Iftekharuddaula, M S Rahman, M H Rashid, S S Dipti, A Islam, M A Latif and A S Islam. 2015. Rice vision for Bangladesh: 2050 and beyond. Bangladesh Rice Journal, 19 (2): 1-18.

Muttaleb, M A, S M Shahidullah, M Nasim and A Saha. 2017. Cropping systems and land use in Sylhet Region. Bangladesh Rice Journal, 21 (2): 273-288.

Nasim, M, S M Shahidullah, A Saha, M A Muttaleb, T L Aditya, M A Ali and M S Kabir. 2017. Distribution of crops and cropping patterns of Bangladesh. Bangladesh Rice Journal, 21 (2): 1-55.

Quais, M K, M H Rashid, S M Shahidullah and M Nasim. 2017. Crops and Cropping Sequences in the Chittagong Hill Tracts. Bangladesh Rice Journal, 21 (2): 173-184. 